\title{
Prevalence and prognostic value of elevated troponins in patients hospitalised for coronavirus disease 2019: a systematic review and meta-analysis
}

Bing-Cheng Zhao ${ }^{1}$, Wei-Feng Liu', Shao-Hui Lei ${ }^{1}$, Bo-Wei Zhou' ${ }^{1}$, Xiao Yang ${ }^{1}$, Tong-Yi Huang ${ }^{2}$, Qi-Wen Deng ${ }^{3}$, Miao $\mathrm{Xu}^{3}$, Cai Li ${ }^{1}$ and Ke-Xuan Liu ${ }^{1 *}$ (i)

\begin{abstract}
Background: The clinical significance of cardiac troponin measurement in patients hospitalised for coronavirus disease 2019 (covid-19) is uncertain. We investigated the prevalence of elevated troponins in these patients and its prognostic value for predicting mortality.

Methods: Studies were identified by searching electronic databases and preprint servers. We included studies of hospitalised covid-19 patients that reported the frequency of troponin elevations above the upper reference limit and/or the association between troponins and mortality. Meta-analyses were performed using random-effects models.

Results: Fifty-one studies were included. Elevated troponins were found in 20.8\% (95\% confidence interval [Cl] 16.8-25.0 \%) of patients who received troponin test on hospital admission. Elevated troponins on admission were associated with a higher risk of subsequent death (risk ratio $2.68,95 \% \mathrm{Cl} 2.08-3.46$ ) after adjusting for confounders in multivariable analysis. The pooled sensitivity of elevated admission troponins for predicting death was 0.60 (95\% $\mathrm{Cl} 0.54-0.65)$, and the specificity was $0.83(0.77-0.88)$. The post-test probability of death was about $42 \%$ for patients with elevated admission troponins and was about $9 \%$ for those with non-elevated troponins on admission. There was significant heterogeneity in the analyses, and many included studies were at risk of bias due to the lack of systematic troponin measurement and inadequate follow-up.
\end{abstract}

Conclusion: Elevated troponins were relatively common in patients hospitalised for covid-19. Troponin measurement on admission might help in risk stratification, especially in identifying patients at high risk of death when troponin levels are elevated. High-quality prospective studies are needed to validate these findings.

Systematic review registration: PROSPERO CRD42020176747

Keywords: Covid-19, Meta-analysis, Myocardial injury, Risk prediction, Troponin

\footnotetext{
*Correspondence: liukexuan705@163.com

'Department of Anaesthesiology, Nanfang Hospital, Southern Medical

University, 1838 Guangzhou Ave N, Guangzhou 510515, China

Full list of author information is available at the end of the article
}

(C) The Author(s). 2020 Open Access This article is licensed under a Creative Commons Attribution 4.0 International License, which permits use, sharing, adaptation, distribution and reproduction in any medium or format, as long as you give appropriate credit to the original author(s) and the source, provide a link to the Creative Commons licence, and indicate if changes were made. The images or other third party material in this article are included in the article's Creative Commons licence, unless indicated otherwise in a credit line to the material. If material is not included in the article's Creative Commons licence and your intended use is not permitted by statutory regulation or exceeds the permitted use, you will need to obtain permission directly from the copyright holder. To view a copy of this licence, visit http://creativecommons.org/licenses/by/4.0/ The Creative Commons Public Domain Dedication waiver (http://creativecommons.org/publicdomain/zero/1.0/) applies to the data made available in this article, unless otherwise stated in a credit line to the data. 


\section{Introduction}

Coronavirus disease 2019 (covid-19) caused by severe acute respiratory syndrome coronavirus-2 (SARS-CoV2) remains a pandemic, with considerable mortality and morbidity exerting pressure on global health-care systems. Patients with covid-19 experience a wide range of disease severity. Prognostic tools that efficiently stratify individual's risk of experiencing adverse outcomes may facilitate patients and clinicians in the informed decision-making process [1].

Despite being primarily a respiratory infection, covid19 has important impacts on many vital organs, including the heart [2, 3]. A growing number of reports have documented myocardial injury reflected by elevated circulating cardiac troponin concentrations among infected patients [4-8]. However, elevated troponins frequently occur in patients with conditions other than acute coronary syndromes, and the mechanisms are complex. For this reason, the American College of Cardiology recommended that troponin is ordered for covid-19 patients only when the diagnosis of acute myocardial infraction is being considered on clinical grounds [9]. On the other hand, the UK National Institute for Health and Care Excellence supported troponin testing for wider indications, including patients with non-specific symptoms of possible myocardial injury such as shortness of breath and severe fatigue [10]. Besides, some opinion papers advocated for systematic troponin testing in all covid-19 patients requiring hospital admission for prognostication purpose $[11,12]$. These conflicting recommendations regarding the use of troponins in evaluating covid-19 patients reflect major gaps in our understanding of the clinical significance of elevated troponins in this context.

Several recent studies have reported on the relevance of elevated troponins to severity of covid-19 and risk of death, including large retrospective studies from major epicentres such as Wuhan, New York City and some European countries as well as studies with prospective designs [13-16]. We undertook a systematic review and meta-analysis to evaluate the prevalence of elevated troponins in hospitalised covid-19 patients, the performance of elevated troponins in predicting mortality and the quality of currently available evidence.

\section{Methods}

This study was conducted following the modified CHAR MS (CHecklist for critical Appraisal and data extraction for systematic Reviews of prediction Modelling Studies) for reviews of prognostic factors (CHARMS-PF) guidelines [17] and reported in accordance with the Preferred Reporting Items for Systematic Reviews and MetaAnalyses (PRISMA) statement (checklist in Table S1) [18]. The study protocol was registered prospectively in PROSPERO (CRD42020176747).

\section{Literature search and eligibility criteria}

We searched English and Chinese databases (PubMed, Embase, Chinese National Knowledge Infrastructure and Chinese Biomedical Database) and preprint servers (medRxiv, bioRxiv, ChinaXiv, Research Square and SSRN) for research articles on covid-19 published after 1 December 2019, with no restrictions on language or peer review status. Details of the search strategy are listed in Table S2. The last update of literature search was performed on 15 October 2020. Studies were considered eligible if they were observational or interventional studies that (1) enrolled patients that required hospitalisation for covid-19 pneumonia, (2) measured cardiac-specific troponin $\mathrm{T}$ or I concentrations on hospital admission or during hospital stay and (3) reported the prevalence of elevated troponins among patients who received troponin measurement or the association between troponin concentrations and mortality during the follow-up. Elevated troponins were defined as troponin concentrations higher than the upper reference limit value predetermined by the local laboratory. We excluded (1) studies that specifically enrolled patients admitted for cardiovascular reasons, organ transplant recipients or deceased patients; (2) studies that reported myocardial injury but the diagnosis was not based solely on troponin measurements or the upper reference limit of troponin test was not used as the diagnostic criteria; and (3) case reports or case series involving fewer than 10 patients. When more than one study from the same institutions with overlapping time period of recruitment were identified, we chose the one with the largest sample size for inclusion, except when our outcomes of interest were reported only in smaller studies.

\section{Study selection, data extraction and quality assessment}

Two researchers (BCZ and WFL) independently screened the identified records, first based on the title and abstract and subsequently based on the full manuscript. The reference lists of relevant manuscripts were searched to identify additional eligible studies. Using predefined forms, both researchers independently extracted data on study design, time of recruitment and follow-up, characteristics of patients and troponin tests, frequency of troponin elevation and, if available, the number of survivors and nonsurvivors among patients with and without elevated troponins. For studies that performed multivariable analysis to assess the association between elevated troponins and mortality, we extracted the adjusted effect estimates with confidence intervals $(\mathrm{CI})$ and the variables in multivariable models. Risk of bias assessment for studies reporting on the prevalence of elevated troponins was conducted using a tool developed for prevalence studies [19]. Key study features assessed were sample selection and measurement quality. The Quality in Prognosis 
Studies (QUIPS) tool was used to assess the risk of bias of studies on the prognostic performance of troponins [20]. The tool includes the evaluation of 6 domains: study participation, study attrition, prognostic factor measurement, outcome assessment, study confounding, and statistical analysis and reporting. Disagreements between researchers were resolved by consensus, and a third researcher was involved when necessary.

\section{Statistical analysis}

Statistical analyses were performed using Stata ${ }^{\circledR}$ version 12.0 (StataCorp, College Station, TX, USA). All metaanalyses were based on random-effects models due to the anticipated high degree of heterogeneity among studies. To estimate the prevalence of elevated troponins in patients admitted for covid-19, we pooled the proportion of patients with elevated troponins among those who received at least one troponin measurement. The Freeman-Tukey double arcsine transformation method was used to account for studies reporting very low prevalence estimates.

To assess the predictive value of troponins for mortality, we pooled the multivariable-adjusted associations between elevated troponins and mortality. For this analysis, studies that did not measure troponins on hospital admission were not included, because troponins are expected to rise in late deterioration of the illness and have less predictive utility at that time. We also excluded studies that modelled troponin as a continuous predictor or did not use the upper reference limit of the troponin test, because the association between troponin concentrations and mortality risk may not be linear and because the use of study-specific optimal cut-off thresholds in meta-analysis may result in overestimation of the prognostic value of a biomarker [21]. We converted adjusted odds ratios reported by included studies to risk ratios (RR) using a published formula [22] and assumed that hazard ratios reasonably approximated RRs. For studies where more than one effect estimates were given for different levels of troponin elevation versus reference, a study-unique effect estimate was generated using a fixed-effects model before being included in the random-effects meta-analysis. We calculated the summary RR with 95\% CI using the generic inverse variance method. Considering that dozens of commercial troponin assays with different epitope targets and analytical characteristics are used in clinical practice, we calculated 95\% prediction intervals (PI) to inform the distribution of prognostic effects of elevated troponins across different measurement methods in future studies [23].

We evaluated publication bias using the funnel plot and Egger's test. When significant publication bias was found, we used trim-and-fill method to adjust our results. The magnitude of heterogeneity was assessed by the Higgins $I^{2}$ statistic. Subgroup analyses in case of substantial heterogeneity $\left(I^{2}>50 \%\right)$ were conducted based on the characteristics of troponin assays (troponin $\mathrm{T}$ or I, high-sensitivity or contemporary assays) and the geographical location, sample size, risk of bias and peer review status of included studies.

The predictive ability of troponin was further assessed by constructing a hierarchical summary receiver operating characteristic curve using the bivariate model [24]. Based on the model, we determined the overall sensitivity, specificity and positive and negative likelihood ratios of elevated troponins on hospital admission for predicting death. These measures of predictive accuracy reflect the intrinsic performance of troponins and are independent of the mortality of underlying study populations. For practical purposes, we estimated the post-test risk of death using the Fagan nomogram, considering a pre-test probability as the pooled risk of death among the included patients.

\section{Results \\ Characteristics of selected studies}

Of the 6124 unique records identified, 51 studies were selected for this review (Fig. 1, Table 1), including 41 studies that have been peer-reviewed [13-16, 25-61] and 10 published only as a preprint [62-71]. Five were prospective studies $[16,32,38,47,58]$ and the others were retrospective in design. Patients included in these studies (sample size range, 15-6247; median age, 44-72 years; proportion of men, 43-79\%) were admitted to hospitals up to 21 June 2020. Information on methods and findings of troponin measurement in each study were summarised in Table 2.

\section{Prevalence of elevated troponins}

In total, 49 studies reported or allowed calculation of prevalence estimates for elevated troponins above the upper reference limit in patients hospitalised for covid19. The risks of bias of these studies in estimating prevalence are summarised in Table S3. The studies differed in patient population (patients admitted to hospital or patients admitted in ICU) and timing of troponin measurement (on admission or during hospital stay). We decided to conduct separate analyses for studies using different methodologies because these may have significant influence on the observed prevalence of elevated troponins.

In 35 studies (22,473 patients) where the prevalence of elevated troponins at the time of hospital admission could be extracted [13-16, 25, 27, 28, 31-39, 43-47, 50, $51,54,55,57,59-61,65-67,69-71]$, the pooled estimate was $20.8 \%$ (95\% CI 16.8-25.0\%) with substantial heterogeneity $\left(I^{2}=98.0 \%\right)$ (Figure S1). No publication bias was suggested by the funnel plot (Figure S2) or the 


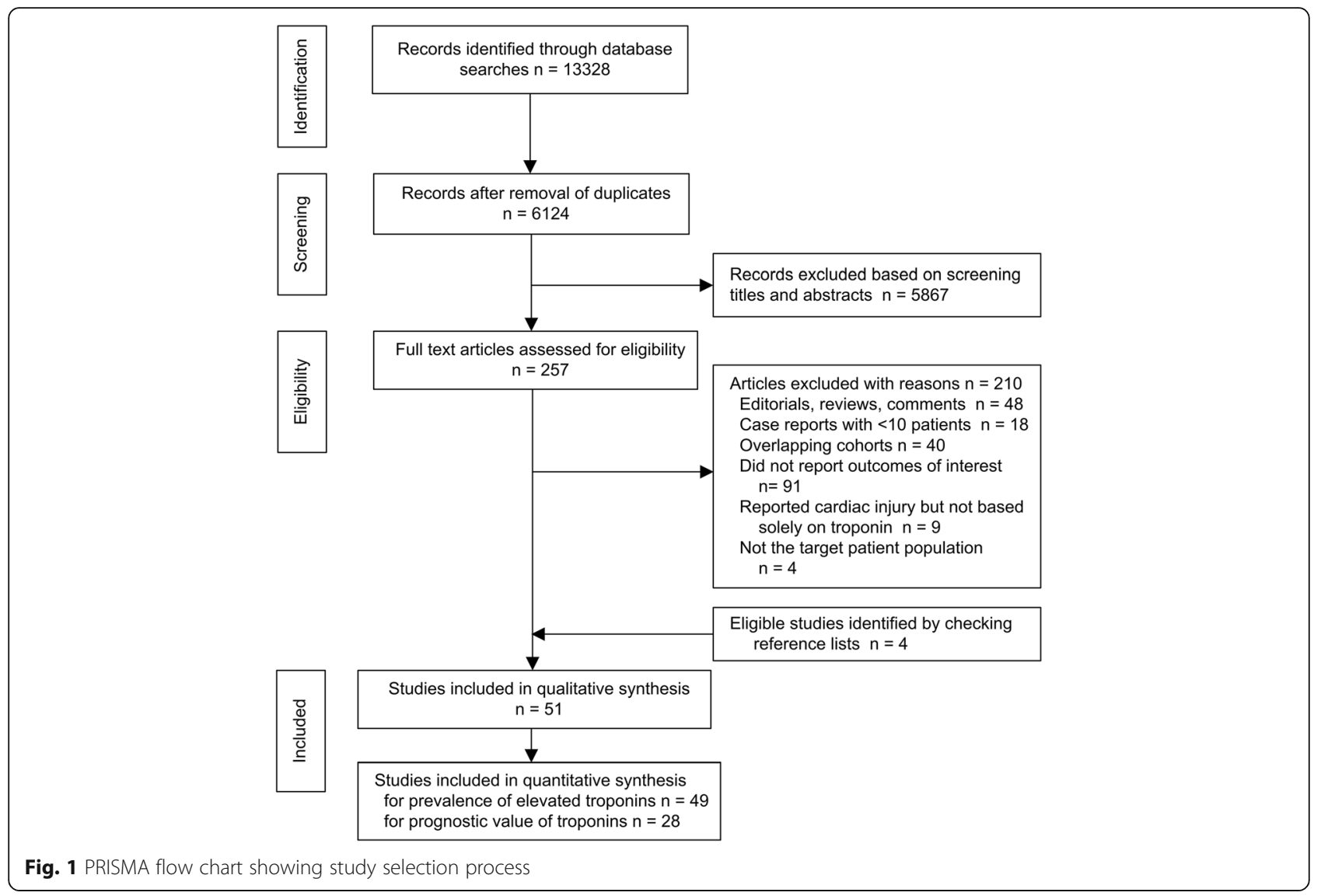

Egger's test $(P=0.292)$. When we exclude studies that measured troponin in less than $90 \%$ of consecutively admitted patients, the remaining 19 studies (5930 patients) deemed at low risk of selection bias yielded a pooled prevalence of $22.9 \%$ (95\% CI 17.6-28.6 \%).

In 9 studies (1470 patients) [30, 31, 34, 41, 48, 52, 53, $56,64]$, the prevalence of elevated troponins during the course of hospital stay was reported; the pooled estimate was 34.2\% (95\% CI 26.2-42.6\%) (Figure S3). Seven studies (814 patients) enrolled only patients admitted to ICU $[26,29,40,42,58,62,63]$, and the pooled prevalence of elevated troponins was 38.0\% (95\% CI 28.2-48.3\%) (Figure S4).

\section{Elevated troponins and mortality}

In 28 studies [13-15, 25-27, 31, 32, 34, 37, 38, 41, 43$46,48,49,51,52,55,57,61,65,67,68,70,71]$, data on the relationship between troponins (on admission or during hospital stay) and mortality of patients with covid-19 could be extracted. The risks of bias of these studies in assessing the prognostic value of troponins are summarised in Table S4. Many of the studies were at high risk of selection bias due to the lack of systematic troponin measurement and incomplete in-hospital follow-up. Besides, 10 studies did not adjust for relevant confounders (e.g. age, cardiovascular comorbidities). The results of studies that conducted multivariable analysis and the confounders adjusted for were listed in Table S5. In the following analyses, we focused only on studies that measured troponins on hospital admission, because troponin tests at this point of time might be useful for early risk stratification, whereas tests ordered during hospitalisation may have been a response to patients' deteriorating conditions and thus would have more diagnostic but less predictive values.

We conducted a meta-analysis of 11 studies $(13,889$ patients) that reported multivariable-adjusted associations between admission troponins above the upper reference limit and mortality [13-15, 26, 27, 32, 37, 45, 46, 55, 67]. Elevated troponins on admission were associated with an increased risk of death (RR 2.68, 95\% CI 2.08-3.46). There was substantial heterogeneity $\left(I^{2}=76.2 \%\right)$; the $95 \%$ prediction interval was wide (1.12-5.94) but did not include 1 (Fig. 2). Possible publication bias was found by the funnel plot (Figure S5a) but not confirmed by the Egger's test $(P=0.203)$. We conducted a sensitivity analysis using the trim-and-fill method, which confirmed the stability of the association (RR 2.59, 95\% CI 2.01-3.35) (Figure S5b). When we excluded 5 studies judged as having high risk of bias from meta-analysis, elevated troponins on admission remained a significant risk 


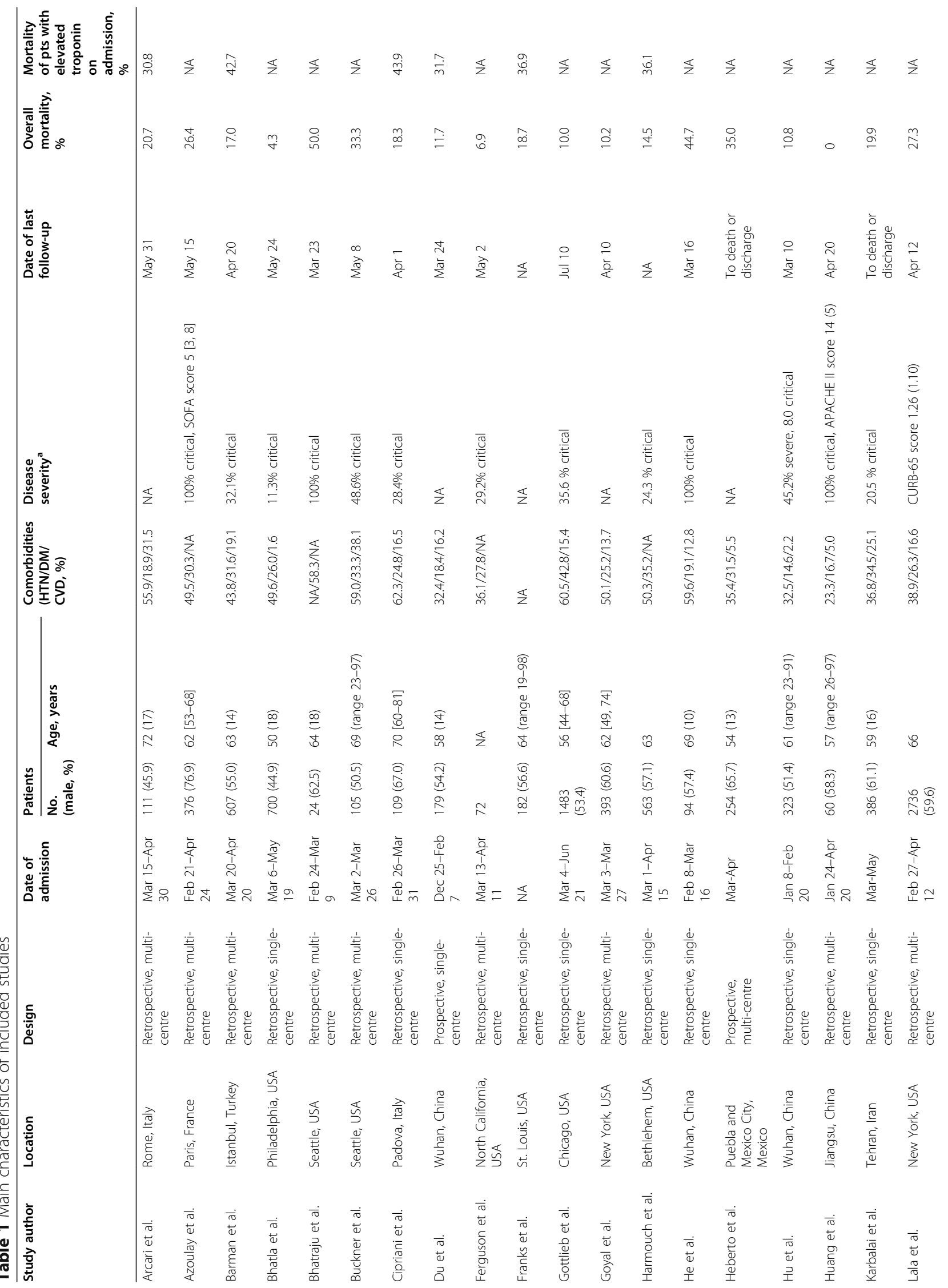




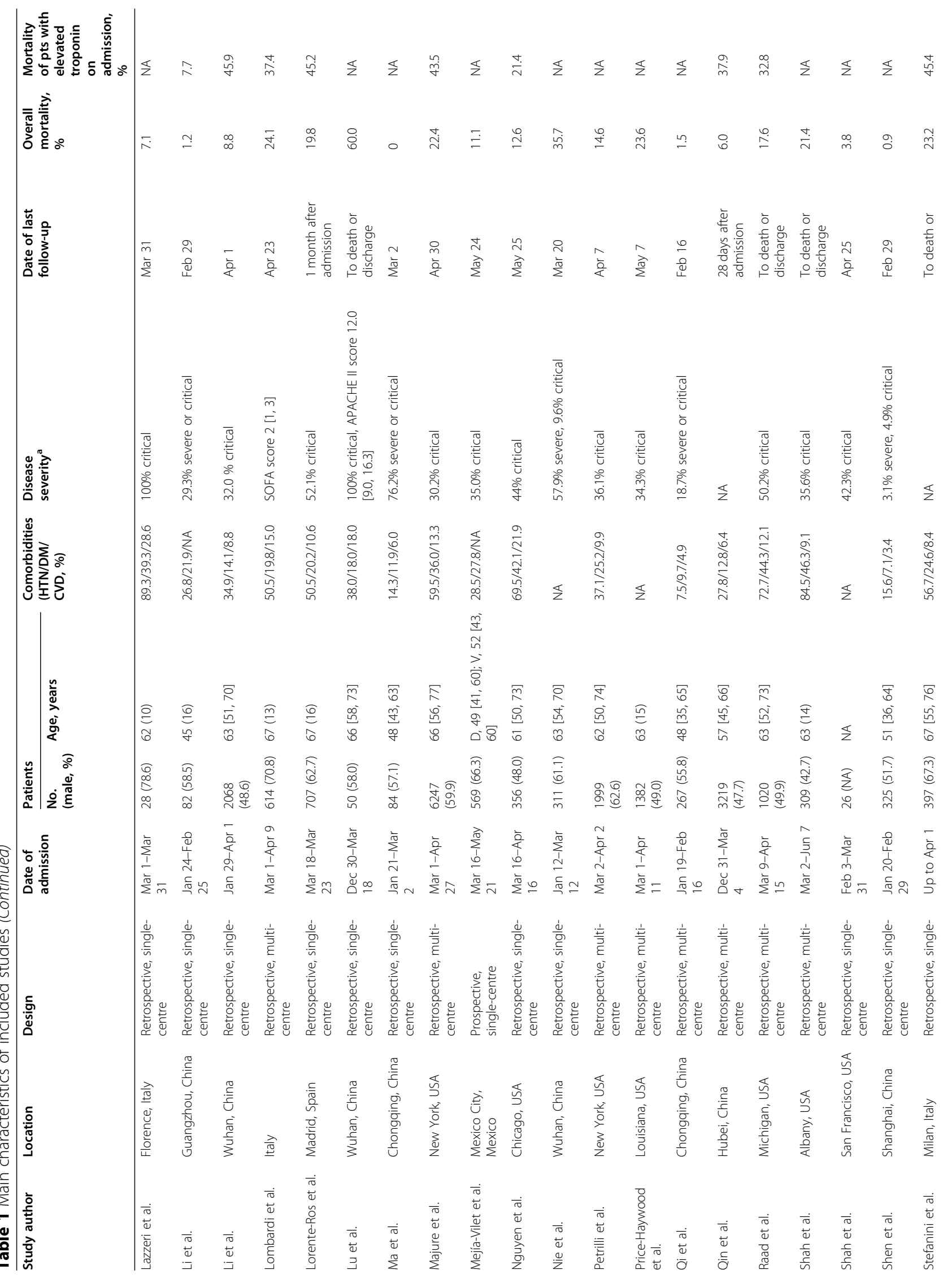




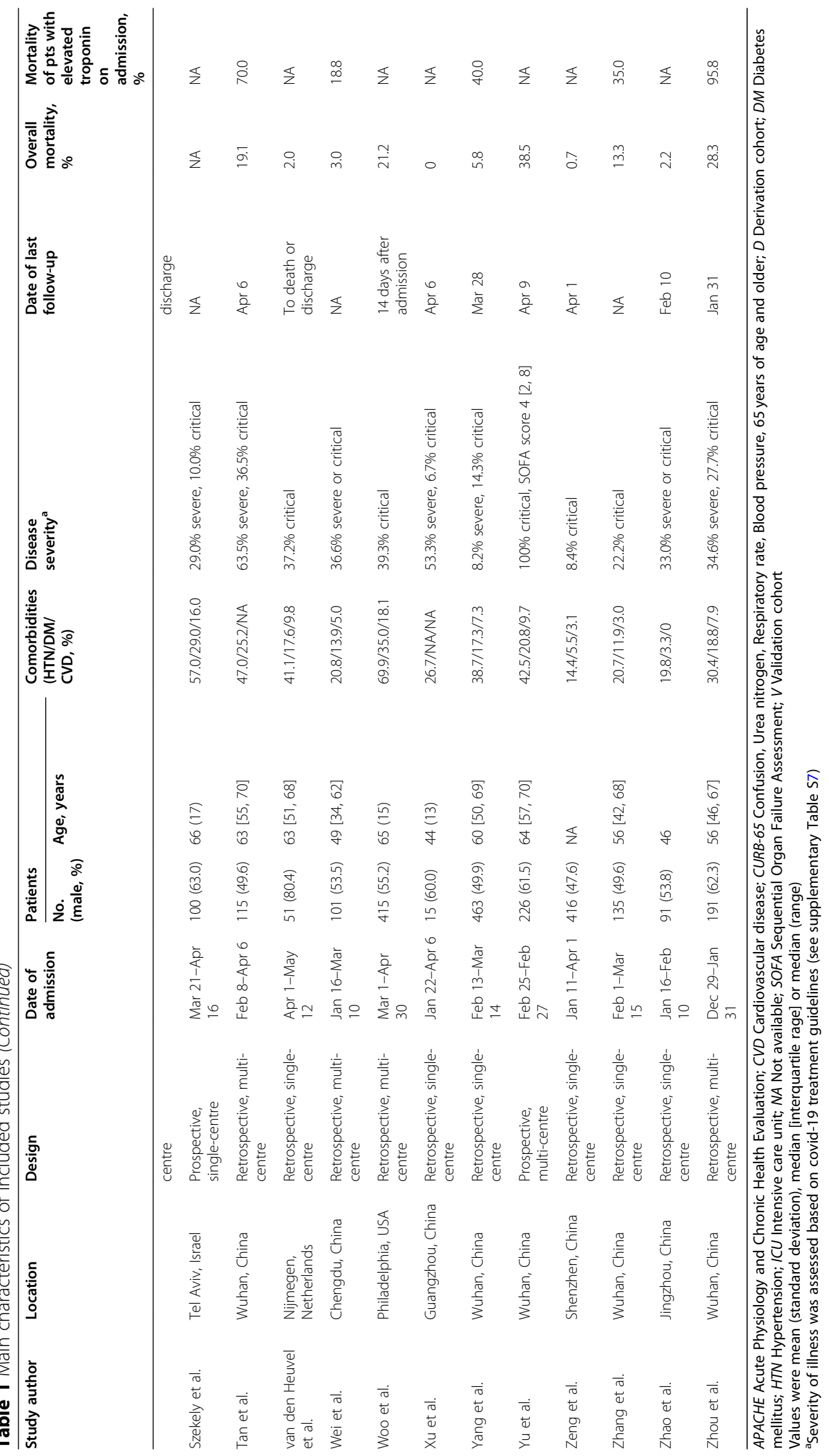


Table 2 Information on troponin measurement in included studies

\begin{tabular}{|c|c|c|c|c|c|c|}
\hline Study & $\begin{array}{l}\text { Type of } \\
\text { Tn } \\
\text { assay }\end{array}$ & Manufacturer & $\begin{array}{l}\text { Upper reference } \\
\text { limit }\end{array}$ & $\begin{array}{l}\text { Time of } \\
\text { measurement }\end{array}$ & $\begin{array}{l}\text { Proportion of patients with Tn } \\
\text { measurement, no. measured/no. } \\
\text { enrolled (\%) }\end{array}$ & $\begin{array}{l}\text { Frequency of Tn } \\
\text { elevation, no. elevated/ } \\
\text { no. measured (\%) }\end{array}$ \\
\hline Arcari et al. & $\begin{array}{l}\text { hs-TnT, } \\
\text { hs-Tnl }\end{array}$ & Roche, NA & $14 \mathrm{ng} / \mathrm{L}, 35 \mathrm{ng} / \mathrm{L}$ & $\begin{array}{l}\text { Within } 24 \mathrm{~h} \text { of } \\
\text { admission }\end{array}$ & 103/111 (92.8) & $39 / 103(37.9)$ \\
\hline $\begin{array}{l}\text { Azoulay } \\
\text { et al. }\end{array}$ & NA & NA & NA & On ICU admission & $343 / 379(90.5)$ & 135/343 (39.4) \\
\hline $\begin{array}{l}\text { Barman } \\
\text { et al. }\end{array}$ & hs-Tnl & NA & $14 \mathrm{ng} / \mathrm{L}$ & On admission & $607 / 908(66.9)$ & $150 / 607(24.7)$ \\
\hline $\begin{array}{l}\text { Bhatla } \\
\text { et al. }\end{array}$ & NA & NA & $0.010 \mathrm{ng} / \mathrm{mL}$ & On admission & $373 / 700(53.3)$ & $82 / 373(22.0)$ \\
\hline $\begin{array}{l}\text { Bhatraju } \\
\text { et al. }\end{array}$ & NA & NA & $0.06 \mathrm{ng} / \mathrm{mL}$ & $\begin{array}{l}\text { During first } 3 \text { days } \\
\text { in ICU }\end{array}$ & $13 / 24(54.2)$ & 2/13 (15.4) \\
\hline $\begin{array}{l}\text { Buckner } \\
\text { et al. }\end{array}$ & NA & NA & $0.1 \mathrm{ng} / \mathrm{mL}$ & $\begin{array}{l}\text { During } \\
\text { hospitalisation }\end{array}$ & 67/105 (63.8) & 13/67 (19.4) \\
\hline $\begin{array}{l}\text { Cipriani } \\
\text { et al. }\end{array}$ & hs-Tnl & NA & $\begin{array}{l}32 \mathrm{ng} / \mathrm{L} \text { for men, } 16 \\
\mathrm{ng} / \mathrm{L} \text { for women }\end{array}$ & $\begin{array}{l}\text { On admission } \\
\text { and during } \\
\text { hospitalisation }\end{array}$ & 109/136 (80.1) & $\begin{array}{l}\text { On admission, 41/109 } \\
\text { (37.6); overall, 46/109 (42.2) }\end{array}$ \\
\hline Du et al. & Tnl & NA & $0.05 \mathrm{ng} / \mathrm{mL}$ & On admission & 179/179 (100) & 41/179 (22.9) \\
\hline $\begin{array}{l}\text { Ferguson } \\
\text { et al. }\end{array}$ & NA & NA & $0.055 \mathrm{ng} / \mathrm{mL}$ & $\begin{array}{l}\text { Within } 24 \mathrm{~h} \text { of } \\
\text { admission }\end{array}$ & $45 / 72(62.5)$ & $2 / 45$ \\
\hline $\begin{array}{l}\text { Franks } \\
\text { et al. }\end{array}$ & Tnl & Abbott & $0.03 \mathrm{ng} / \mathrm{mL}$ & $\begin{array}{l}\text { On admission } \\
\text { and during } \\
\text { hospitalisation }\end{array}$ & $\begin{array}{l}\text { On admission, } \\
\text { 128/182 (70.3); } \\
\text { overall, 143/182 } \\
(78.6)\end{array}$ & $\begin{array}{l}\text { On admission, } 65 / 128 \\
\text { (50.8); overall, 80/143 (55.9) }\end{array}$ \\
\hline $\begin{array}{l}\text { Gottlieb } \\
\text { et al. }\end{array}$ & NA & NA & $0.9 \mathrm{ng} / \mathrm{mL}$ & On admission & $390 / 1483(26.3)$ & $87 / 390(22.3)$ \\
\hline Goyal et al. & NA & NA & $0.5 \mathrm{ng} / \mathrm{mL}$ & $\begin{array}{l}\text { Within } 48 \mathrm{~h} \text { of } \\
\text { admission }\end{array}$ & 246/393 (62.6) & $11 / 246(4.5)$ \\
\hline $\begin{array}{l}\text { Harmouch } \\
\text { et al. }\end{array}$ & $\mathrm{Tnl}$ & NA & $0.05 \mathrm{ng} / \mathrm{mL}$ & On admission & $482 / 560(86.1)$ & $97 / 482(20.1)$ \\
\hline He et al. & hs-Tnl & NA & NA & $\begin{array}{l}\text { During stay in } \\
\text { ICU }\end{array}$ & $94 / 94(100)$ & 35/94 (37.2) \\
\hline $\begin{array}{l}\text { Heberto } \\
\text { et al. }\end{array}$ & hs-Tnl & Beckman & $17.5 \mathrm{ng} / \mathrm{L}$ & On admission & $254 / 254(100)$ & $64 / 254(25.2)$ \\
\hline Hu et al. & $\operatorname{Tnl}$ & Siemens & $0.040 \mathrm{ng} / \mathrm{mL}$ & On admission & $323 / 323(100)$ & $68 / 323(21.1)$ \\
\hline $\begin{array}{l}\text { Huang } \\
\text { et al. }\end{array}$ & TnT & NA & $0.13 \mathrm{ng} / \mathrm{mL}$ & On ICU admission & $60 / 60(100)$ & $19 / 60(31.7)$ \\
\hline $\begin{array}{l}\text { Karbalai } \\
\text { et al. }\end{array}$ & hs-cTnl & NA & $\begin{array}{l}26 \mathrm{ng} / \mathrm{L} \text { for men, } 11 \\
\mathrm{ng} / \mathrm{L} \text { for women }\end{array}$ & $\begin{array}{l}\text { During } \\
\text { hospitalisation }\end{array}$ & $386 / 386(100)$ & 115/386 (29.8) \\
\hline Lala et al. & $\mathrm{Tnl}$ & Abbott & $0.03 \mathrm{ng} / \mathrm{mL}$ & $\begin{array}{l}\text { Within } 24 \mathrm{~h} \text { of } \\
\text { admission }\end{array}$ & 2736/3047 (89.8) & $1751 / 2736(36.0)$ \\
\hline $\begin{array}{l}\text { Lazzeri } \\
\text { et al. }\end{array}$ & TnT & NA & $0.028 \mathrm{ng} / \mathrm{mL}$ & On ICU admission & $28 / 28(100)$ & $11 / 28(39.3)$ \\
\hline Li et al. & Tnl & Beckman & $0.03 \mathrm{ng} / \mathrm{mL}$ & On admission & $82 / 82(100)$ & 13/82 (15.9) \\
\hline Li et al. & hs-Tnl & Abbott & $34.2 \mathrm{ng} / \mathrm{L}$ & On admission & 2068/2699 (76.6) & 181/2068 (8.8) \\
\hline $\begin{array}{l}\text { Lombardi } \\
\text { et al. }\end{array}$ & NA & NA & NA & $\begin{array}{l}\text { Within } 24 \text { hours } \\
\text { of admission }\end{array}$ & $614 / 614(100)$ & $278 / 614(45.3)$ \\
\hline $\begin{array}{l}\text { Lorente- } \\
\text { Ros et al. }\end{array}$ & hs-Tnl & NA & $14 \mathrm{ng} / \mathrm{L}$ & On admission & 707/707 (100) & 148/707 (20.9) \\
\hline Lu et al. & Tnl & NA & $0.4 \mathrm{ng} / \mathrm{mL}$ & $\begin{array}{l}\text { During stay in } \\
\text { ICU }\end{array}$ & $50 / 72(69.4)$ & $36 / 50(72.0)$ \\
\hline Ma K, et al & Tnl & NA & $0.034 \mathrm{ng} / \mathrm{mL}$ & $\begin{array}{l}\text { During } \\
\text { hospitalisation }\end{array}$ & $84 / 84(100)$ & 9/84 (10.7) \\
\hline Majure & Tnl, Tnl, & Siemens, & $0.045 \mathrm{ng} / \mathrm{mL}, 0.056$ & Within 48 hours & $6247 / 11,159(56.0)$ & $1821 / 6247(29.1)$ \\
\hline
\end{tabular}


Table 2 Information on troponin measurement in included studies (Continued)

\begin{tabular}{|c|c|c|c|c|c|c|}
\hline Study & $\begin{array}{l}\text { Type of } \\
\text { Tn } \\
\text { assay }\end{array}$ & Manufacturer & $\begin{array}{l}\text { Upper reference } \\
\text { limit }\end{array}$ & $\begin{array}{l}\text { Time of } \\
\text { measurement }\end{array}$ & $\begin{array}{l}\text { Proportion of patients with Tn } \\
\text { measurement, no. measured/no. } \\
\text { enrolled (\%) }\end{array}$ & $\begin{array}{l}\text { Frequency of Tn } \\
\text { elevation, no. elevated/ } \\
\text { no. measured (\%) }\end{array}$ \\
\hline et al. & $\begin{array}{l}\text { TnT, hs- } \\
\text { TnT }\end{array}$ & $\begin{array}{l}\text { Siemens, } \\
\text { Roche, Roche }\end{array}$ & $\begin{array}{l}\mathrm{ng} / \mathrm{mL}, 0.01 \mathrm{ng} / \mathrm{mL} \text {, } \\
19 \mathrm{ng} / \mathrm{L}\end{array}$ & of admission & & \\
\hline $\begin{array}{l}\text { Mejía-Vilet } \\
\text { et al. }\end{array}$ & Tnl & NA & $0.020 \mathrm{ng} / \mathrm{mL}$ & On admission & $569 / 569(100)$ & $86 / 569(15.1)$ \\
\hline $\begin{array}{l}\text { Nguyen } \\
\text { et al. }\end{array}$ & hs-Tnl & NA & $22 \mathrm{ng} / \mathrm{L}$ & On admission & $340 / 356(95.5)$ & $140 / 340(41.2)$ \\
\hline Nie et al. & hs-Tnl & Abbott & $26.2 \mathrm{ng} / \mathrm{L}$ & $\begin{array}{l}\text { During } \\
\text { hospitalisation }\end{array}$ & NA & 103/311 (33.1) \\
\hline $\begin{array}{l}\text { Petrilli } \\
\text { et al. }\end{array}$ & NA & NA & $0.1 \mathrm{ng} / \mathrm{mL}$ & On admission & $2510 / 2729(92.0)$ & NA \\
\hline $\begin{array}{l}\text { Price- } \\
\text { Haywood } \\
\text { et al. }\end{array}$ & Tnl & NA & $0.06 \mathrm{ng} / \mathrm{mL}$ & On admission & 1084/1382 (78.4) & 270/1084 (24.9) \\
\hline Qi et al. & hs-TnT & Roche & $14 \mathrm{ng} / \mathrm{L}$ & On admission & $76 / 267(28.5)$ & $3 / 76(3.9)$ \\
\hline Qin et al. & $\begin{array}{l}\text { hs-Tnl, } \\
\text { Tnl }\end{array}$ & Various & Various & On admission & $1462 / 6033(24.2)$ & $95 / 1462(6.5)$ \\
\hline Raad et al. & hs-Tnl & Beckman & $18 \mathrm{ng} / \mathrm{L}$ & On admission & 1020/1044 (97.7) & $390 / 1020(38.2)$ \\
\hline Shah et al. & Tnl & NA & $0.05 \mathrm{ng} / \mathrm{mL}$ & $\begin{array}{l}\text { During } \\
\text { hospitalisation }\end{array}$ & $309 / 635(48.7)$ & $116 / 309$ (37.5) \\
\hline Shah et al. & Tnl & NA & $0.05 \mathrm{ng} / \mathrm{mL}$ & $\begin{array}{l}\text { During } \\
\text { hospitalisation }\end{array}$ & $14 / 26(53.8)$ & $5 / 14(35.7)$ \\
\hline Shen et al. & Tnl & Siemens & $0.040 \mathrm{ng} / \mathrm{mL}$ & On admission & $325 / 325(100)$ & $80 / 325(24.6)$ \\
\hline $\begin{array}{l}\text { Stefanini } \\
\text { et al. }\end{array}$ & hs-Tnl & Beckman & 19.6 ng/L & On admission & $397 / 397(100)$ & 130/397 (32.7) \\
\hline $\begin{array}{l}\text { Szekely } \\
\text { et al. }\end{array}$ & Tnl & Abbott & $28 \mathrm{ng} / \mathrm{L}$ & On admission & $100 / 100(100)$ & 20/100 (20) \\
\hline Tan et al. & hs-Tnl & Abbott & $26.2 \mathrm{ng} / \mathrm{L}$ & On admission & $115 / 115(100)$ & 20/115 (17.4) \\
\hline $\begin{array}{l}\text { van den } \\
\text { Heuvel } \\
\text { et al. }\end{array}$ & hs-TnT & Roche & $14 \mathrm{ng} / \mathrm{L}$ & $\begin{array}{l}\text { During } \\
\text { hospitalisation }\end{array}$ & $47 / 51(92.2)$ & $24 / 47(51.1)$ \\
\hline Wei et al. & hs-TnT & Roche & $14 \mathrm{ng} / \mathrm{L}$ & On admission & 101/103 (98.1) & 16/101 (15.8) \\
\hline Woo et al. & $\begin{array}{l}\text { hs-TnT, } \\
\text { Tnl }\end{array}$ & $\begin{array}{l}\text { Roche, } \\
\text { Siemens }\end{array}$ & $\begin{array}{l}19 \mathrm{ng} / \mathrm{L}, 0.040 \mathrm{ng} / \\
\mathrm{mL}\end{array}$ & On admission & NA & NA \\
\hline Xu et al. & $\mathrm{Tnl}$ & NA & NA & On admission & $15 / 15(100)$ & $1 / 15(6.7)$ \\
\hline Yang et al. & Tnl & Siemens & $0.040 \mathrm{ng} / \mathrm{mL}$ & On admission & $463 / 463(100)$ & 45/463 (9.7) \\
\hline Yu et al. & $\begin{array}{l}\text { hs-Tnl, } \\
\text { Tnl }\end{array}$ & Abbott, NA & $28 \mathrm{ng} / \mathrm{L}, 0.3 \mathrm{ng} / \mathrm{mL}$ & $\begin{array}{l}\text { During stay in } \\
\text { ICU }\end{array}$ & $226 / 226(100)$ & $61 / 226(27.0)$ \\
\hline Zeng et al. & Tnl & NA & $0.026 \mathrm{ng} / \mathrm{mL}$ & On admission & $345 / 416(82.9)$ & 29/345 (8.4) \\
\hline $\begin{array}{l}\text { Zhang } \\
\text { et al. }\end{array}$ & hs-TnT & Roche & $14 \mathrm{ng} / \mathrm{L}$ & On admission & 135/135 (100) & 40/135 (29.6) \\
\hline Zhao et al. & Tnl & NA & $0.01 \mathrm{ng} / \mathrm{mL}$ & On admission & $88 / 91(96.7)$ & $3 / 88(3.4)$ \\
\hline Zhou et al. & hs-Tnl & Abbott & $28 \mathrm{ng} / \mathrm{L}$ & On admission & 145/191 (75.9) & 24/145 (16.6) \\
\hline
\end{tabular}

Hs High-sensitivity, ICU Intensive care unit, NA Not available, Tn Troponin

factor for subsequent death (RR 2.08, 95\% CI 1.81-2.40), and the heterogeneity was eliminated $\left(I^{2}=0 \%\right)$. The results of subgroup analyses were shown in Table S6.

To further characterise the predictive performance of troponins, we included 20 studies (15,488 patients) that reported the number of deaths in those admitted with elevated and non-elevated troponins in a bivariate metaanalysis $[14,15,25,27,31,32,34,37,43-46,51,55,57$, $61,65,67,70,71]$. The overall sensitivity of elevated troponins on admission for predicting death was 0.60 (95\% CI $0.54-0.65)$; the specificity was $0.83(0.77-0.88)$ (Fig. 3). The positive and negative likelihood ratios were 3.61 


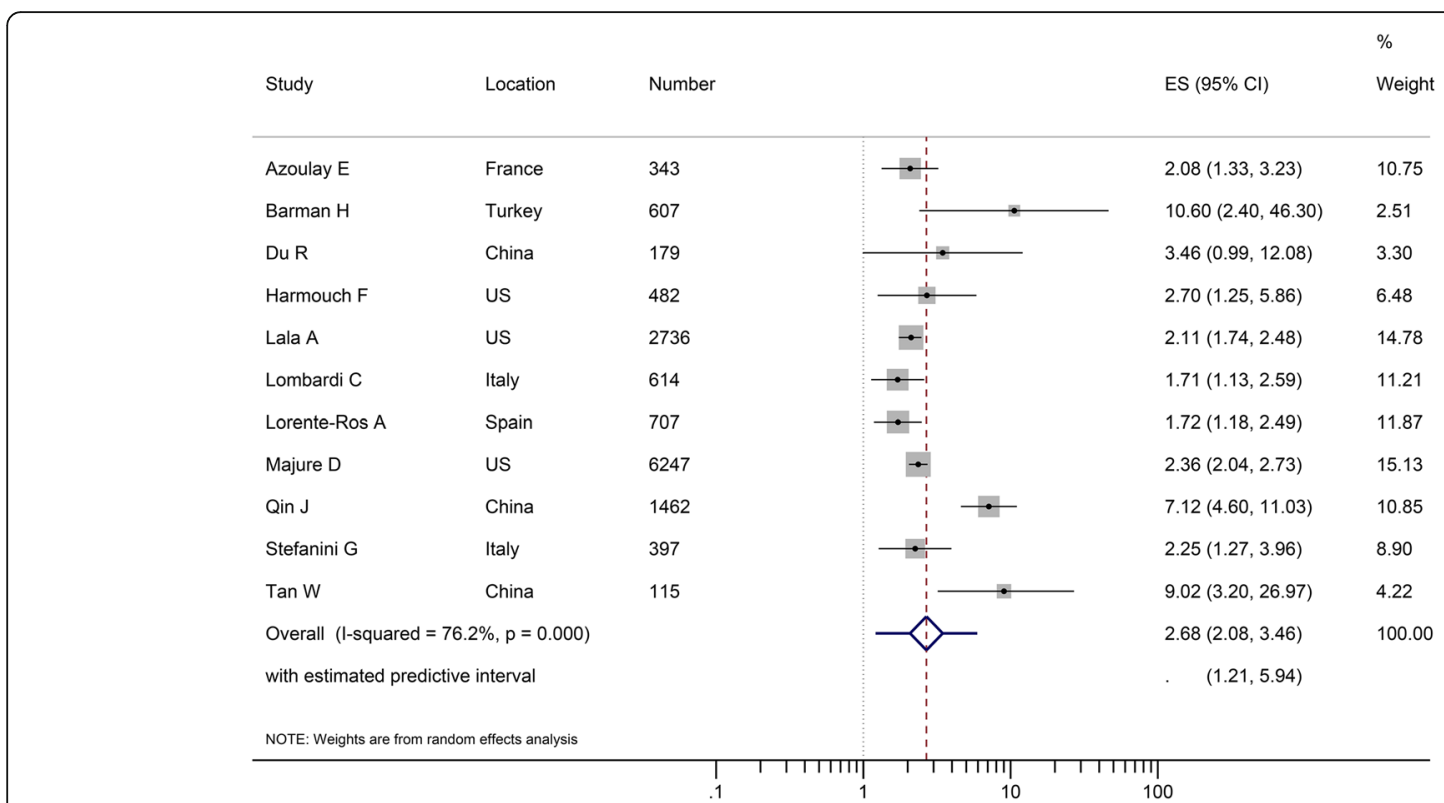

Fig. 2 Forest plot showing the confounder-adjusted association between elevated troponins on hospital admission and mortality, quantified as risk ratio (RR) of death in patients with elevated troponins relative to those with non-elevated troponins. $\mathrm{Cl}$, confidence interval

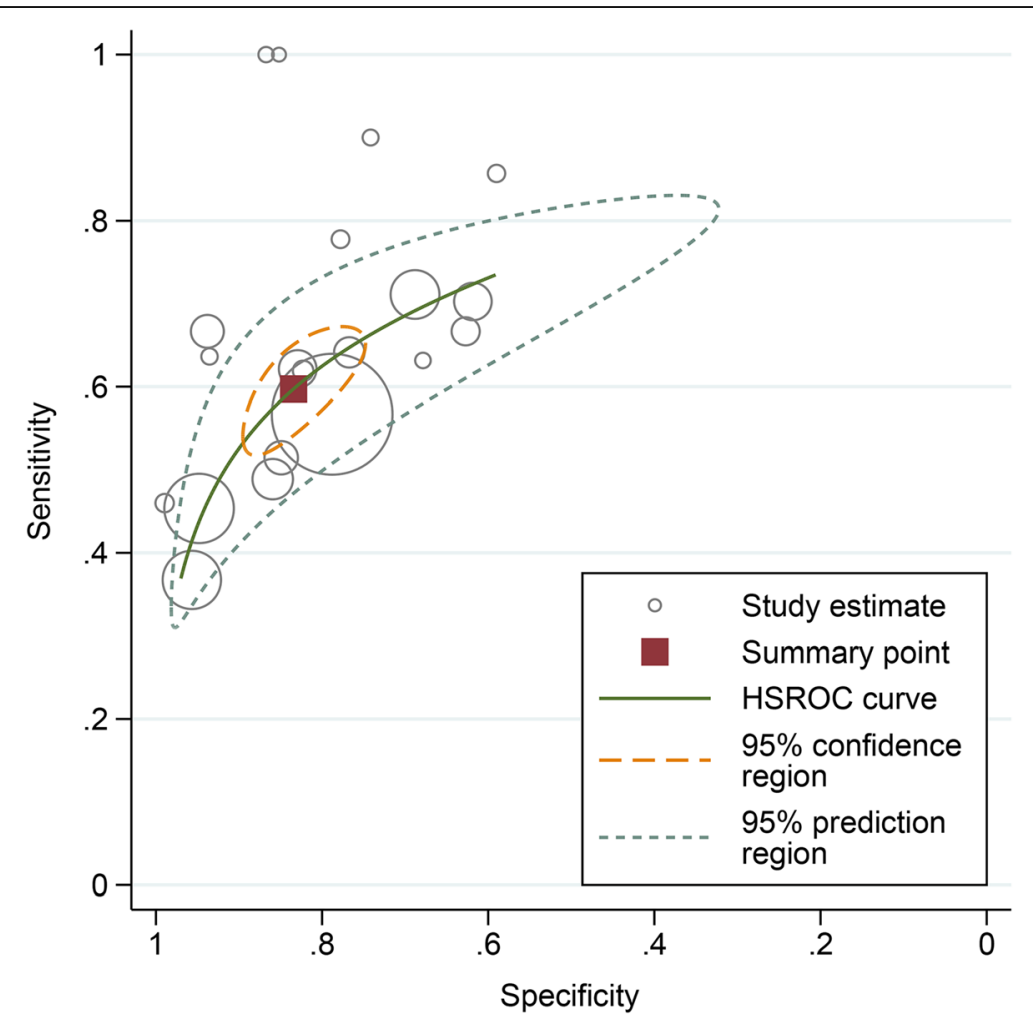

Fig. 3 Performance of troponins on admission for predicting mortality. The brown square represents the summary operating point of the curve that summarises the prognostic performance of troponins (sensitivity $0.60,95 \% \mathrm{Cl} 0.54-0.65$; specificity $0.83,95 \% \mathrm{Cl} 0.77-0.88$; positive likelihood ratio 3.61 , $95 \% \mathrm{Cl} 2.74-4.70$; negative likelihood ratio $0.48,95 \% \mathrm{Cl} 0.43-0.54)$. The area under the hierarchical summary receiver operating characteristic curve was $0.74,95 \%$ Cl 0.70-0.78. 


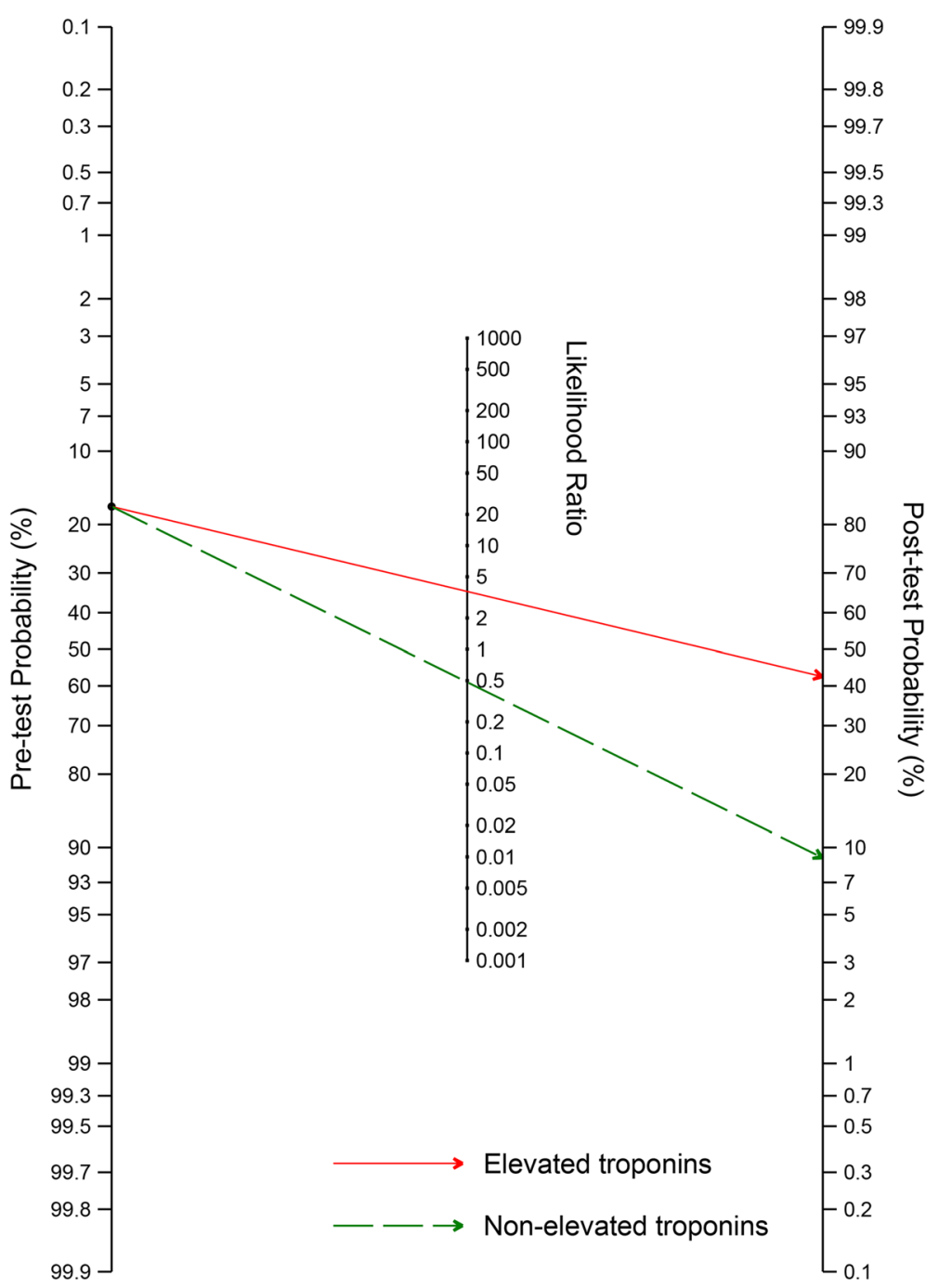

Fig. 4 Fagan nomogram for calculation of post-test probability of death based on elevated (red) or non-elevated (green) troponins on admission. The Fagan nomogram is based on a pre-test probability of 17\%, which is the pooled mortality estimate in 20 included studies, a positive likelihood ratio of 3.61 , and a negative likelihood ratio of 0.48

(2.74-4.70) and $0.48(0.43-0.54)$, respectively. Considering a pre-test probability of death of $17 \%$ (the pooled estimate from the 20 included studies), the post-test probability of death for patients with elevated troponins on admission was approximately $42 \%$, while that of patients with nonelevated troponins on admission was approximately $9 \%$ (Fig. 4).

\section{Discussion}

The findings of this systematic review and meta-analysis demonstrated that elevated troponins are relatively common in patients hospitalised for covid-19 and appear to be independently associated with death.

Elevated troponins had a pooled prevalence of $20.8 \%$ in patients with covid-19 on hospital admission. The estimate appeared higher when the troponin concentrations during hospital stay was considered and in patients admitted to ICU. Our findings are consistent with those of previous studies showing that myocardial injury occurs frequently in patients with severe respiratory infections caused by other viruses or bacteria [72-74]. Common mechanisms of myocardial injury in these conditions may include oxygen supply-demand mismatch, systemic hyperinflammation, and microvascular dysfunction and thrombosis. Besides, recent pathological and imaging studies indicated that acute atherosclerotic plaque rupture, stress cardiomyopathy, direct cardiomyocytes damage by the SARS-CoV-2 virus and myocarditis may also be the causes of troponin elevation in some patients with covid-19 [7578]. We observed significant heterogeneity in the prevalence of elevated troponins across individual studies, which is likely attributable to several factors. The 
demographics and burden of comorbidities of patient populations from different countries may be different. Besides, there are no universal criteria for hospital admission for covid-19 patients; the criteria may vary across different places and different phases of the disease spread. These resulted in considerable heterogeneity among study cohorts in baseline characteristics such as age, cardiovascular diseases and the severity of respiratory infection, which would produce widely varying frequencies of elevated troponins. Moreover, multiple troponin assays with different analytical sensitivities were used for assessing myocardial injury. Studies that used high-sensitivity assays may find higher prevalence of elevated troponins than those using less sensitive earlier-generation troponin assays. Despite the heterogeneity, our pooled estimate with a relatively narrow confidence interval represents a substantial minority of patients with elevated troponins on hospital admission, indicating an important involvement of the heart in severe forms of covid-19.

Similar to findings in patients with other severe respiratory illnesses, elevated troponins appeared to have prognostic implications for patients admitted for covid19. Some recent systematic reviews and meta-analyses have reported on the associations between elevated troponins and adverse outcomes of covid-19 [5-8, 79, 80]. However, there are several limitations to these analyses, including not accounting for the time point of troponin measurements and the cut-off threshold for troponin elevation, the variability in outcome definitions, the lack of adjustment for confounders and the inclusion of overlapping cohorts in analysis. In this study, we addressed the predictive value of troponin by focusing on troponin measured on hospital admission and on the hard outcome of death. We found that admission troponin concentrations higher than the upper reference limit were associated with a more than twofold risk of death in multivariable analyses. The stability of this association was supported by various sensitivity and subgroup analyses. Thus, troponin testing may provide prognostic information independent of other routinely assessed demographic and clinical factors for covid-19 patients early on patient admission, so that it might help clinicians in triage decision-making. Our results suggested that measurement of troponin levels at the time of hospital admission for covid-19 might be included in the diagnostic workup to identify patients at increased risk of worse outcome and those who may require higher level of surveillance and more intensive treatment.

In addition, our bivariate analysis suggested that troponin may be especially helpful to identify patients at high mortality risk when it is elevated. However, the prognosis of patients with normal troponin levels was still worrisome (mortality of $\sim 9 \%$ ). This is not surprising because injuries in other organ systems during the course of disease are also important factors of death [81]. Thus, the detection of a normal troponin level at hospital admission may not be considered as a sign of very low mortality risk or criteria for early discharge. The combination of troponin with other clinical information might achieve more accurate prognostication than either alone [45].

While higher mortality rates of patients with elevated troponins were consistently reported by the included studies, only two studies ascertained the mechanisms of death of patients $[14,15]$. Interestingly, there was no significant difference in causes of death between patients with or without elevated troponin who deceased. It might be hypothesised that elevated troponins reflect the severity of involvement of different organs and tissues in covid-19 patients and may predict higher mortality of both cardiovascular and non-cardiovascular causes.

We acknowledge several limitations to our metaanalysis. There is significant heterogeneity in the prevalence of elevated troponins on admission and the strength of their association with mortality, presumably reflecting differing patient background, troponin assays and therapeutic practices among study centres. In addition, many of the included studies did not measure troponin systematically for all patients on their admission, and the indications for troponin measurement were poorly reported. Selective troponin sampling may have resulted in a systematic overestimation of the prevalence of elevated troponins in these studies. However, our pooled analysis of 19 studies at low risk of bias (studies that measured troponin concentrations on admission in $>90 \%$ of patients) yielded similar prevalence estimate. On the other hand, patients that did not received troponin measurement tended to have milder illness, lower prevalence of myocardial injury and lower risks of subsequent death [49]. Thus, their exclusion might have biassed the observed strength of association between elevated troponins and death toward a smaller magnitude. Overall, while we cannot be certain about the accuracy of estimates for the prevalence of elevated troponins and the associated risk of death, we believe that important inferences can still be made. Across a heterogeneous group of patients hospitalised for covid-19, myocardial injury reflected by troponin concentrations above the upper reference limit was relatively common and did consistently correlate with excess risk of death.

In this study, despite that we evaluated the association between elevated troponins and death based on multivariable analyses, our result may still be subject to residual confounding. Baseline comorbidities such as cardiovascular and kidney diseases are both strongly associated with higher troponin concentrations and are independent risk factors for mortality of covid-19 [82, 83], but they were not fully adjusted for in some of the 
included studies. However, dissecting the relative contributions of entwined conditions of pre-existing chronic myocardial injury, new-onset acute myocardial injury and reduced troponin clearance caused by renal impairment may be impossible, even if individual patient data from original studies were available. Thus, we could not address the question whether covid-19 infection-related myocardial injury directly influences the survival of patients. However, this limitation should not detract from the potential value of elevated troponins as a marker for early identification of covid-19 patients at high risk of death.

Other limitations of this study included the fact that we could not evaluate the utility of serial troponin testing during the first few days after admission in the identification of and risk assessment for patients with myocardial injury, because single troponin measurements on admission were reported in most studies. In addition, we were not able to evaluate the long-term impact of elevated troponins on admission or during hospital stay on the cardiovascular health of covid-19 survivors. Given the limitations of available evidence, the justification of measuring troponin as a prognostic tool for patients hospitalised for covid-19 warrants further investigation. Ongoing registries that systematically collect cardiovascular data in covid-19 patients, such as the CAPACITY-COVID [84], will hopefully contribute to a better understanding of the implications of troponin measurements in patients with covid-19.

\section{Conclusion}

The present meta-analysis suggests that among patients hospitalised for covid-19, admission troponin concentrations above the upper reference limit are common and are predictive for subsequent death. Clinically, the presence of elevated troponins on admission may facilitate risk stratification by enabling early identification of patients at high mortality risk. Large prospective studies with systematic troponin sampling and adequate followup are needed to validate the prognostic implications of elevated troponins for patients admitted for covid-19.

\section{Supplementary Information}

The online version contains supplementary material available at https://doi. org/10.1186/s40560-020-00508-6.

Additional file 1: Table S1. Preferred Reporting Items for Systematic Reviews and Meta-Analyses (PRISMA) checklist. Table S2. Literature search strategy (PubMed as example). Table S3. Risk of bias assessment for studies on the prevalence of elevated troponin in patients hospitalised for covid-19. Table S4. Quality in Prognostic Studies (QUIPS) risk of bias assessment for studies on the association between elevated troponin and mortality. Table S5. Multivariable-adjusted association between elevated troponin and mortality in patients hospitalised for covid-19. Table S6. Subgroup analyses on the prognostic value of elevated troponins on admission for predicting death. Table S7. Covid-19 severity of illness classification. Figure S1. Pooled prevalence of elevated troponins on hospital admission. Figure S2. Funnel plot for assessing publication bias in the prevalence of elevated troponins on hospital admission. Figure S3. Pooled prevalence of elevated troponins during hospital stay. Figure S4. Pooled prevalence of elevated troponins in patients admitted to intensive care unit. Figure S5. (a) Funnel plot for assessing publication bias in the association between elevated admission troponins and mortality risk. (b) Funnel plot after applying the trim-and-fill method.

\section{Abbreviations \\ Covid-19: Coronavirus disease 2019; SARS-CoV2: Severe acute respiratory syndrome coronavirus-2; CHARMS: CHecklist for critical Appraisal and data extraction for systematic Reviews of prediction Modelling Studies; PRIS \\ MA: Preferred Reporting Items for Systematic Reviews and Meta-Analyses; Cl: Confidence interval; QUIPS: Quality in Prognosis Studies; RR: Risk ratio; Pl: Prediction interval}

\section{Acknowledgements}

None.

\section{Authors' contributions}

BCZ, WFL and SHL conceived the study, conducted literature search, extracted data, performed statistical analysis and drafted the manuscript. $X Y$, TYH and QWD extracted data, performed statistical analysis and helped in interpreting the data and drafting the manuscript. BWZ, MX, CL and KXL helped in data interpretation and critically revised the manuscript. BCZ, WFL and SHL contributed equally to the work. The author(s) read and approved the final manuscript.

\section{Funding}

This work was supported by the Guangdong Basic and Applied Basic Research Foundation [2019A1515110655 to Bing-Cheng Zhao] and the Science and Technology Project of Guangdong Province [2014A020212660 to Miao Xu].

Availability of data and materials

The datasets used and/or analysed during the current study are available from the corresponding author on reasonable request.

Ethics approval and consent to participate

Not applicable.

Consent for publication

Not applicable.

\section{Competing interests}

The authors declare that they have no competing interests.

\section{Author details}

${ }^{1}$ Department of Anaesthesiology, Nanfang Hospital, Southern Medical University, 1838 Guangzhou Ave N, Guangzhou 510515, China. ²Department of Medical Ultrasound, Institute of Diagnostic and Interventional Ultrasound, The First Affiliated Hospital, Sun Yat-Sen University, 58 Zhongshan 2nd Road, Guangzhou 510080, China. ${ }^{3}$ Department of Anaesthesiology, The First Affiliated Hospital, Sun Yat-Sen University, 58 Zhongshan 2nd Road, Guangzhou 510080, China.

Received: 31 July 2020 Accepted: 15 November 2020 Published online: 23 November 2020

\section{References}

1. Wynants L, Van Calster B, Collins GS, Riley RD, Heinze G, Schuit E, et al. Prediction models for diagnosis and prognosis of covid-19 infection: systematic review and critical appraisal. BMJ. 2020;369:m1328.

2. Liu PP, Blet A, Smyth D, Li H. The science underlying COVID-19: implications for the cardiovascular system. Circulation. 2020;142(1):68-78.

3. Guzik TJ, Mohiddin SA, Dimarco A, Patel V, Savvatis K, Marelli-Berg FM, et al. COVID-19 and the cardiovascular system: implications for risk assessment, diagnosis, and treatment options. Cardiovasc Res. 2020;116(10):1666-87. 
4. Bavishi C, Bonow RO, Trivedi V, Abbott JD, Messerli FH, Bhatt DL. Acute myocardial injury in patients hospitalized with COVID-19 infection: A review. Prog Cardiovasc Dis. 2020.

5. Li JW, Han TW, Woodward M, Anderson CS, Zhou H, Chen YD, et al. The impact of 2019 novel coronavirus on heart injury: a systematic review and meta-analysis. Prog Cardiovasc Dis. 2020;63(4):518-24.

6. Li X, Guan B, Su T, Liu W, Chen M, Bin Waleed K, et al. Impact of cardiovascular disease and cardiac injury on in-hospital mortality in patients with COVID-19: a systematic review and meta-analysis. Heart. 2020;106(15):1142-7.

7. Parohan M, Yaghoubi S, Seraji A. Cardiac injury is associated with severe outcome and death in patients with Coronavirus disease 2019 (COVID-19) infection: a systematic review and meta-analysis of observational studies. Eur Heart J Acute Cardiovasc Care. 2020;9(6):665-77.

8. Santoso A, Pranata R, Wibowo A, Al-Farabi MJ, Huang I, Antariksa B. Cardiac injury is associated with mortality and critically ill pneumonia in COVID-19: A meta-analysis. Am J Emerg Med. 2020.

9. Januzzi JL. Troponin and BNP use in COVID-19. American College of Cardiology. https://www.acc.org/latest-in-cardiology/articles/2020/03/1 8/15/25/troponin-and-bnp-use-in-covid19. Accessed 21 Oct 2020.

10. NICE guideline [NG171]. Covid-19 rapid guideline: acute myocardial injury. National Institute for Health and Care Excellence. https://www.nice.org.uk/ guidance/NG171. Accessed 21 Oct 2020.

11. Chapman AR, Bularga A, Mills NL. High-sensitivity cardiac troponin can be an ally in the fight against COVID-19. Circulation. 2020;141(22):1733-5.

12. Loungani RS, Rehorn MR, Newby LK, Katz JN, Klem I, Mentz RJ, et al. A care pathway for the cardiovascular complications of COVID-19: insights from an institutional response. Am Heart J. 2020;225:3-9.

13. Lala A, Johnson KW, Januzzi JL, Russak AJ, Paranjpe I, Richter F, et al. Prevalence and impact of myocardial injury in patients hospitalized with covid-19 infection. J Am Coll Cardiol. 2020;76(5):533-46.

14. Lombardi CM, Carubelli V, lorio A, Inciardi RM, Bellasi A, Canale C, et al. Association of troponin levels with mortality in Italian patients hospitalized with coronavirus disease 2019: results of a multicenter study. JAMA Cardiol. 2020;5(11):1274-80.

15. Qin JJ, Cheng X, Zhou F, Lei F, Akolkar G, Cai J, et al. Redefining cardiac biomarkers in predicting mortality of inpatients with COVID-19. Hypertension. 2020;76(4):1104-12.

16. Szekely Y, Lichter $Y$, Taieb P, Banai A, Hochstadt A, Merdler I, et al. Spectrum of cardiac manifestations in COVID-19: a systematic echocardiographic study. Circulation. 2020;142(4):342-53.

17. Riley RD, Moons KGM, Snell KIE, Ensor J, Hooft L, Altman DG, et al. A guide to systematic review and meta-analysis of prognostic factor studies. BMJ. 2019;364:k4597.

18. Moher D, Liberati A, Tetzlaff J, Altman DG, Group P. Preferred reporting items for systematic reviews and meta-analyses: the PRISMA statement. PLoS Med. 2009;6(7):e1000097.

19. Hoy D, Brooks P, Woolf A, Blyth F, March L, Bain C, et al. Assessing risk of bias in prevalence studies: modification of an existing tool and evidence of interrater agreement. J Clin Epidemiol. 2012;65(9):934-9.

20. Hayden JA, van der Windt DA, Cartwright JL, Cote P, Bombardier C. Assessing bias in studies of prognostic factors. Ann Intern Med. 2013;158(4):280-6.

21. Potgieter D, Simmers D, Ryan L, Biccard BM, Lurati-Buse GA, Cardinale DM, et al. N-terminal pro-B-type natriuretic peptides' prognostic utility is overestimated in meta-analyses using study-specific optimal diagnostic thresholds. Anesthesiology. 2015;123(2):264-71.

22. Grant RL. Converting an odds ratio to a range of plausible relative risks for better communication of research findings. BMJ. 2014;348:f7450.

23. Riley RD, Elia EG, Malin G, Hemming K, Price MP. Multivariate meta-analysis of prognostic factor studies with multiple cut-points and/or methods of measurement. Stat Med. 2015;34(17):2481-96.

24. Lee J, Kim KW, Choi SH, Huh J, Park SH. Systematic review and meta-analysis of studies evaluating diagnostic test accuracy: A practical review for clinical researchers-Part II. Statistical methods of meta-analysis. Korean J Radiol. 2015;16(6):1188-96.

25. Arcari L, Luciani M, Cacciotti L, Musumeci MB, Spuntarelli V, Pistella E, et al. Incidence and determinants of high-sensitivity troponin and natriuretic peptides elevation at admission in hospitalized COVID-19 pneumonia patients. Intern Emerg Med. 2020;15(8):1467-76.

26. Azoulay E, Fartoukh M, Darmon M, Geri G, Voiriot G, Dupont T, et al. Increased mortality in patients with severe SARS-CoV-2 infection admitted within seven days of disease onset. Intensive Care Med. 2020;46(9):1714-22.
27. Barman HA, Atici A, Sahin I, Alici G, Aktas Tekin E, Baycan OF, et al. Prognostic significance of cardiac injury in COVID-19 patients with and without coronary artery disease. Coron Artery Dis. 2020.

28. Bhatla A, Mayer MM, Adusumalli S, Hyman MC, Oh E, Tierney A, et al. COVID-19 and cardiac arrhythmias. Heart Rhythm. 2020;17(9):1439-44.

29. Bhatraju PK, Ghassemieh BJ, Nichols M, Kim R, Jerome KR, Nalla AK, et al. Covid-19 in critically ill patients in the Seattle region - case series. N Engl J Med. 2020;382(21):2012-22.

30. Buckner FS, McCulloch DJ, Atluri V, Blain M, McGuffin SA, Nalla AK, et al. Clinical features and outcomes of 105 hospitalized patients with COVID-19 in Seattle, Washington. Clin Infect Dis. 2020;71(16):2167-73.

31. Cipriani A, Capone F, Donato F, Molinari L, Ceccato D, Saller A, et al. Cardiac injury and mortality in patients with Coronavirus disease 2019 (COVID-19): insights from a mediation analysis. Intern Emerg Med. 2020.

32. Du RH, Liang LR, Yang CQ, Wang W, Cao TZ, Li M, et al. Predictors of mortality for patients with COVID-19 pneumonia caused by SARS-CoV-2: a prospective cohort study. Eur Respir J. 2020;55(5):2000524.

33. Ferguson J, Rosser Jl, Quintero O, Scott J, Subramanian A, Gumma M, et al. Characteristics and outcomes of coronavirus disease patients under nonsurge conditions, Northern California, USA, March-April 2020. Emerg Infect Dis. 2020:26(8):1679-85.

34. Franks CE, Scott MG, Farnsworth CW. Elevated cardiac troponin I is associated with poor outcomes in COVID-19 patients at an academic medical center in midwestern USA. J Appl Lab Med. 2020;5(5):1137-9.

35. Gottlieb M, Sansom S, Frankenberger C, Ward E, Hota B. Clinical course and factors associated with hospitalization and critical illness among COVID-19 patients in Chicago, Illinois. Acad Emerg Med. 2020;27(10):963-73.

36. Goyal P, Choi JJ, Pinheiro LC, Schenck EJ, Chen R, Jabri A, et al. Clinical characteristics of Covid-19 in New York City. N Engl J Med. 2020;382(24): 2372-4.

37. Harmouch F, Shah K, Hippen JT, Kumar A, Goel H. Is it all in the heart? Myocardial injury as major predictor of mortality among hospitalized COVID-19 patients. J Med Virol. 2020.

38. Heberto AB, Carlos PCJ, Antonio CRJ, Patricia PP, Enrique TR, Danira MPJ, et al. Implications of myocardial injury in Mexican hospitalized patients with coronavirus disease 2019 (COVID-19). Int J Cardiol Heart Vasc. 2020;30: 100638.

39. Hu L, Chen S, Fu Y, Gao Z, Long H, Wang JM, et al. Risk factors associated with clinical outcomes in 323 COVID-19 hospitalized patients in Wuhan, China. Clin Infect Dis. 2020;71(16):2089.

40. Huang M, Yang Y, Shang F, Zheng Y, Zhao W, Luo L, et al. Clinical characteristics and predictors of disease progression in severe patients with COVID-19 infection in Jiangsu province, China: a descriptive study. Am J Med Sci. 2020;360(2):120-8.

41. Karbalai Saleh S, Oraii A, Soleimani A, Hadadi A, Shajari Z, Montazeri M, et al. The association between cardiac injury and outcomes in hospitalized patients with COVID-19. Intern Emerg Med. 2020;15(8):1415-24.

42. Lazzeri C, Bonizzoli M, Batacchi S, Cianchi G, Franci A, Fulceri GE, et al. Cardiac involvment in COVID-19-related acute respiratory distress syndrome. Am J Cardiol. 2020;132:147-9.

43. Li C, Li M, Gan L, Zhang Y, Lei CL. Heart and liver damage in coronavirus disease-2019. Guang Dong Yi Xue. 2020;41:874-7.

44. Li C, Jiang J, Wang F, Zhou N, Veronese G, Moslehi JJ, et al. Longitudinal correlation of biomarkers of cardiac injury, inflammation, and coagulation to outcome in hospitalized COVID-19 patients. J Mol Cell Cardiol. 2020;147:74-87.

45. Lorente-Ros A, Monteagudo Ruiz JM, Rincon LM, Ortega Perez R, Rivas S, Martinez-Moya $R$, et al. Myocardial injury determination improves risk stratification and predicts mortality in COVID-19 patients. Cardiol J. 2020; 27(5):489-96.

46. Majure DT, Gruberg L, Saba SG, Kvasnovsky C, Hirsch JS, Jauhar R. Usefulness of elevated troponin to predict death in patients with COVID-19 and myocardial injury. Int J Cardiol. 2020;S0002-9149(20):31097-3.

47. Mejía-Vilet JM, Cordova-Sanchez BM, Fernandez-Camargo DA, Mendez-Perez RA, Morales-Buenrostro LE, Hernandez-Gilsoul T. A risk score to predict admission to the intensive care unit in patients with Covid-19: the ABCGOALS score. Salud Publica Mex. 2020.

48. Nie SF, Yu M, Xie T, Yang F, Wang HB, Wang ZH, et al. Cardiac troponin I is an independent predictor for mortality in hospitalized patients with COVID19. Circulation. 2020;142(6):608-10.

49. Petrilli CM, Jones SA, Yang J, Rajagopalan H, O'Donnell L, Chernyak Y, et al. Factors associated with hospital admission and critical illness among 5279 
people with coronavirus disease 2019 in New York City: prospective cohort study. BMJ. 2020;369:m1966.

50. Price-Haywood EG, Burton J, Fort D, Seoane L. Hospitalization and mortality among black patients and white patients with covid-19. N Engl J Med. 2020;382(26):2534-43.

51. Raad M, Dabbagh M, Gorgis S, Yan J, Chehab O, Dagher C, et al. Cardiac injury patterns and inpatient outcomes among patients admitted with COVID-19. Am J Cardiol. 2020;133:154-61.

52. Shah P, Doshi R, Chenna A, Owens R, Cobb A, Ivey H, et al. Prognostic value of elevated cardiac troponin $\mathrm{i}$ in hospitalized covid-19 patients. Am J Cardiol. 2020;135:150-3.

53. Shah SJ, Barish PN, Prasad PA, Kistler A, Neff N, Kamm J, et al. Clinical features, diagnostics, and outcomes of patients presenting with acute respiratory illness: a retrospective cohort study of patients with and without COVID-19. EClinicalMedicine. 2020;27:100518.

54. Shen Y, Zheng F, Sun D, Ling Y, Chen J, Li F, et al. Epidemiology and clinical course of COVID-19 in Shanghai, China. Emerg Microbes Infect. 2020;9(1): $1537-45$.

55. Stefanini GG, Chiarito M, Ferrante G, Cannata F, Azzolini E, Viggiani G, et al. Early detection of elevated cardiac biomarkers to optimise risk stratification in patients with COVID-19. Heart. 2020;106(19):1512-8.

56. van den Heuvel FMA, Vos JL, Koop Y, van Dijk APJ, Duijnhouwer AL, de Mast $Q$, et al. Cardiac function in relation to myocardial injury in hospitalised patients with COVID-19. Neth Heart J. 2020;28(7-8):410-7.

57. Wei JF, Huang FY, Xiong TY, Liu Q, Chen H, Wang $H$, et al. Acute myocardial injury is common in patients with COVID-19 and impairs their prognosis. Heart. 2020;106(15):1154-9.

58. Yu Y, Xu D, Fu S, Zhang J, Yang X, Xu L, et al. Patients with COVID-19 in 19 ICUs in Wuhan, China: a cross-sectional study. Crit Care. 2020;24(1):219.

59. Zeng JH, Wu WB, Qu JX, Wang Y, Dong CF, Luo YF, et al. Cardiac manifestations of COVID-19 in Shenzhen, China. Infection. 2020;48(6):861-70.

60. Zhao XY, Xu XX, Yin HS, Hu QM, Xiong T, Tang YY, et al. Clinical characteristics of patients with 2019 coronavirus disease in a non-Wuhan area of Hubei Province, China: a retrospective study. BMC Infect Dis. 2020; 20(1):311.

61. Zhou F, Yu T, Du R, Fan G, Liu Y, Liu Z, et al. Clinical course and risk factors for mortality of adult inpatients with COVID-19 in Wuhan, China: a retrospective cohort study. Lancet. 2020:395(10229):1054-62.

62. He H, Jin Z, Ren Y, Wang J, Wen W, Miao Y, et al. Clinical course and features of critical patients with COVID-19: a single-center, retrospective study from Wuhan Huoshenshan Hospital. Res Square. 2020; [Preprint]

63. Lu S, He H, Ra L, Wu Y, Deng L, Wang P, et al. The Cardiac Injury in Hospitalized Patients with Severe COVID-19 in Wuhan, China. Res Square. 2020; [Preprint].

64. Ma K-L, Liu Z-H, Cao C-F, Liu M-K, Liao J, Zou J-B, et al. COVID-19 myocarditis and severity factors: an adult cohort study. medRxiv. 2020; [Preprint].

65. Nguyen AB, Upadhyay GA, Chung B, Smith B, Besser SA, Johnson JA, et al. Outcomes and Cardiovascular Comorbidities in a Predominantly AfricanAmerican Population with COVID-19. medRxiv. 2020; [Preprint].

66. Qi D, Yan X, Tang X, Peng J, Yu Q, Feng L, et al. Epidemiological and clinical features of 2019-nCoV acute respiratory disease cases in Chongqing municipality, China: a retrospective, descriptive, multiple-center study. medRxiv. 2020; [Preprint].

67. Tan W, Zhu Y, Yi H, Lin Y, Liu Y, Wu Z, et al. Development a Nomogram to Predict Prognosis in Severe and Critically III Patients with COVID-19. Res Square. 2020; [Preprint].

68. Woo S, Rios-Diaz A, Kubey A, Cheney-Peters D, Ackermann L, Chalikonda D, et al. Development and validation of a web-based severe COVID-19 risk prediction model. medRxiv. 2020; [Preprint].

69. Xu W, Luo Q, Chen D, Lei Z, Chen Y, Wang J, et al. Clinical features in mild type and severe type of COVID-19 patients. Res Square. 2020; [Preprint].

70. Yang $S$, Ma L, Wang Y-L, Wang Q, Tong Q, Chen M, et al. Risk factors for critical-ill events of patients with COVID-19 in Wuhan, China: a retrospective cohort study. medRxiv. 2020; [Preprint].

71. Zhang J, Ding D, Cao C, Zhang J, Huang X, Fu P, et al. Myocardial characteristics as the prognosis for COVID-19 patients. medRxiv. 2020; [Preprint].

72. Gao C, Wang Y, Gu X, Shen X, Zhou D, Zhou S, et al. Association between cardiac injury and mortality in hospitalized patients infected with avian influenza A (H7N9) virus. Crit Care Med. 2020;48(4):451-8.
73. Pizzini A, Burkert F, Theurl I, Weiss G, Bellmann-Weiler R. Prognostic impact of high sensitive troponin $T$ in patients with influenza virus infection: A retrospective analysis. Heart Lung. 2020;49(1):105-9.

74. Vestjens SMT, Spoorenberg SMC, Rijkers GT, Grutters JC, Ten Berg JM, Noordzij PG, et al. High-sensitivity cardiac troponin T predicts mortality after hospitalization for community-acquired pneumonia. Respirology. 2017;22(5):1000-6.

75. Imazio M, Klingel K, Kindermann I, Brucato A, De Rosa FG, Adler $Y$, et al. COVID-19 pandemic and troponin: indirect myocardial injury, myocardial inflammation or myocarditis? Heart. 2020;106(15):1127-31.

76. Tersalvi G, Vicenzi M, Calabretta D, Biasco L, Pedrazzini G, Winterton D. Elevated troponin in patients with coronavirus disease 2019: possible mechanisms. J Card Fail. 2020;26(6):470-5.

77. Lindner D, Fitzek A, Brauninger $H$, Aleshcheva G, Edler C, Meissner K, et al. Association of cardiac infection with SARS-CoV-2 in confirmed COVID-19 autopsy cases. JAMA Cardiol. 2020;5(11):1281-5.

78. Puntmann VO, Carerj ML, Wieters I, Fahim M, Arendt C, Hoffmann J, et al. Outcomes of cardiovascular magnetic resonance imaging in patients recently recovered from coronavirus disease 2019 (COVID-19). JAMA Cardiol. 2020;5(11):1265-73.

79. Aikawa T, Takagi H, Ishikawa K, Kuno T. Myocardial injury characterized by elevated cardiac troponin and in-hospital mortality of COVID-19: An insight from a meta-analysis. J Med Virol. 2020.

80. Vrsalovic M, Vrsalovic PA. Cardiac troponins predict mortality in patients with COVID-19: A meta-analysis of adjusted risk estimates. J Infect. 2020; 81(3):e99-e100

81. Potere N, Valeriani E, Candeloro M, Tana M, Porreca E, Abbate A, et al. Acute complications and mortality in hospitalized patients with coronavirus disease 2019: a systematic review and meta-analysis. Crit Care. 2020;24(1):389.

82. Chen R, Liang W, Jiang M, Guan W, Zhan C, Wang T, et al. Risk factors of fatal outcome in hospitalized subjects with coronavirus disease 2019 from a nationwide analysis in China. Chest. 2020;158(1):97-105.

83. Cheng $Y$, Luo R, Wang $K$, Zhang M, Wang Z, Dong L, et al. Kidney disease is associated with in-hospital death of patients with COVID-19. Kidney Int. 2020;97(5):829-38

84. Linschoten M, Asselbergs FW. CAPACITY-COVID: a European Registry to determine the role of cardiovascular disease in the COVID-19 pandemic. Eur Heart J. 2020;41(19):1795-6.

\section{Publisher's Note}

Springer Nature remains neutral with regard to jurisdictional claims in published maps and institutional affiliations.

Ready to submit your research? Choose BMC and benefit from:

- fast, convenient online submission

- thorough peer review by experienced researchers in your field

- rapid publication on acceptance

- support for research data, including large and complex data types

- gold Open Access which fosters wider collaboration and increased citations

- maximum visibility for your research: over $100 \mathrm{M}$ website views per year

At $\mathrm{BMC}$, research is always in progress.

Learn more biomedcentral.com/submissions 